\title{
IMPROVEMENT OF COAL FLY ASH POZZOLANIC ACTIVITY BY DIFFERENT PHYSICAL METHODS
}

\author{
I. Jovanović $c^{1, \#, ~ L j . ~ A n d r i c ́ ~}{ }^{2}$, M. Bugarin ${ }^{1}$, D. Urošević ${ }^{1}$, S. Bugarinović \\ ${ }^{1}$ Mining and Metallurgy Institute Bor, Zeleni bulevar 35, Bor, Serbia \\ ${ }^{2}$ Institute for Technology of Nuclear and Other Mineral Raw Materials, \\ Bulevar Franše d'Eperea 86, Belgrade, Serbia
}

(Received: September 2, 2013; Accepted: March 3, 2014)

\begin{abstract}
This paper presents the results of laboratory investigations performed in order to determine the possibility of improving the pozzolanic activity of coal fly ash from two Serbian Thermal Power Plants. The initial samples of fly ash were treated by different physical processes (mechanical activation, grinding and classification). On the obtained samples, the pozzolanic activity was determined using standard methods (with lime and Portland cement). It was found that the above procedures can significantly improve the pozzolanic activity of fly ash, and the best results were achieved when the fly ash was treated by mechanical activation process in the laboratory ring mill.
\end{abstract}

Key words: fly ash, pozzolanic activity, physical processes, mechanical activation.

\section{Introduction}

Fly ash is the finest fraction of coal combustion residue with grain size $0-1 \mathrm{~mm}$, which is intercepted in separators. It is a heterogeneous material formed by particles with different physical, chemical, mineralogical, morphological and technological properties, which are determined and influenced by the quality of burned coal, technology of combustion and conditions of combustion [8]. It is generally known, that the fly ash has been used as cement additive due to its pozzolanic properties $[16,1]$.

Standard ASTM C618 defines three classes of pozzolans: Class N, Class F, and Class C. Class $\mathrm{N}$ includes raw or calcined natural pozzolan such as some diatomaceous earths, opaline cherts and shales; tuffs, volcanic ashes or pumicites; calcined clays (including metakaolin) and shales. Class $\mathrm{F}$ is pozzolanic fly ash normally produced from burning anthracite or bituminous coal. Class $\mathrm{C}$ is pozzolanic and cementitious fly ash normally produced from burning lignite or subbituminous coal. Fly ash, used in this investigation belongs to the F Class.

A typical property of pozzolans is their ability to react with lime or Portland cement in the presence of water. $\mathrm{SiO}_{2}$ and $\mathrm{Al}_{2} \mathrm{O}_{3}$ from fly ash react with calcium hydroxide $\mathrm{Ca}(\mathrm{OH})_{2}$ and hydrated calcium silicate compounds as well as hydrated calcium aluminate compounds are formed. These newly-created substances are not soluble in water.

This ability of pozzolans, labeled as a pozzolanic activity is connected with a form of present $\mathrm{SiO}_{2}$ and $\mathrm{Al}_{2} \mathrm{O}_{3}$. [9]. Namely, fly ashes show the higher reactivity if the amount of glass phase (which contains amorphous aluminosilicates) is higher, i.e. if the content of crystalline components (quartz, mullite) is

\#Corresponding author: ivajo7@gmail.com 
lower. Also, the fineness of fly ash is one of the most important properties affecting pozzolanic activity. [2, 10,7].

Considering characteristics of fly ash, this material can be applied in the production of hydraulic binders and concrete (especially in the production of Portland cement clinker, as an active admixture to partly substitute cement, or as a filling material i.e. aggregate) $[4,11,3]$. Due to its pozzolanic character, fly ash can improve the quality of concrete, upgrade its processability and upgrade pumpability of the concrete mixture [6, 19, 17]. Except for that, fly ash takes effects on reducing formation of crakes, limit the creep of concrete, increase water impermeability, and improve resistance against frost and aggressive effects $[5,12,18]$. In accordance with the above text, the aim of this study was to increase pozzolanic activity of silicate fly ash using different physical methods: mechanical activation (i.e. very fine grinding), grinding and classifying.

Table 1. Physical-mechanical characteristics of Portland cement

\begin{tabular}{|c|c|c|c|c|c|c|}
\hline \multicolumn{3}{|c|}{ Flexural strength [MPa] } & \multicolumn{3}{|c|}{ Compressive strength [MPa] } & \multirow{2}{*}{$\begin{array}{c}\text { Residue on } \\
\text { sieve o. s. } \\
90 \mu \mathrm{m}[\%]\end{array}$} \\
\hline 2 days & 7 days & 28 days & 2 days & 7 days & 28 days & \\
\hline 6.1 & 7.3 & 8.7 & 28.8 & 42.5 & 58.3 & 1.2 \\
\hline \multirow{3}{*}{$\begin{array}{c}\text { Water } \\
\text { requirement } \\
\text { for } \\
\text { standard } \\
\text { consist. }[\mathrm{ml}]\end{array}$} & \multicolumn{2}{|c|}{ Setting time } & \multicolumn{4}{|c|}{ Soundness } \\
\hline & \multirow[b]{2}{*}{$\begin{array}{c}\text { initial } \\
{[h: \min ]}\end{array}$} & \multirow[b]{2}{*}{$\begin{array}{c}\text { final } \\
{[h: \min ]}\end{array}$} & \multicolumn{3}{|c|}{ cement specimens } & \multirow[b]{2}{*}{$\begin{array}{c}\text { Le Chatelier's } \\
\text { method }\end{array}$} \\
\hline & & & in water & in the air & boiled & \\
\hline 24.7 & $3: 45$ & $4: 40$ & $\begin{array}{c}\text { without } \\
\text { deformations }\end{array}$ & $\begin{array}{c}\text { without } \\
\text { deformations }\end{array}$ & $\begin{array}{c}\text { without } \\
\text { deformations }\end{array}$ & $\begin{array}{c}\text { without } \\
\text { deformations }\end{array}$ \\
\hline
\end{tabular}

\section{Experimental}

\subsection{Raw materials}

Coal fly ash samples were taken from two Serbian Thermal Power Plants. The first sample (FA 1) was taken from TPP Nikola Tesla - Obrenovac and the second sample (FA 2) was taken from TPP Kostolac. Portland cement sample (PC), which was used during testing, was obtained by grinding of Portland cement clinker and calcium sulfate to appropriate fineness. (Mass share of $\mathrm{CaSO}_{4}$ in Portland cement was 5\%). Table 1 shows physical-mechanical characteristics of Portland cement sample. Chemical compositions of fly ashes and Portland cement are shown in the Table 2 .
On the basis of the results shown in Tables 1 and 2, this cement accomplished the requirements for chemical, physical and mechanical properties, defined by valid Standard EN 197-1:2000 and belongs to the type PC $52.5 \mathrm{~N}$. Particularly, the high compressive strength of $58.3 \mathrm{MPa}$ developed by this cement after 28 days of hardening, should be highlighted as a measure of its quality. As it can be seen from the Table 2, chemical compositions of fly ash samples fully satisfy the requirements of standard ASTM C618, for fly ash type F. Both of fly ashes belong to distinctly alumino-siliceous materials with a high amount of $\mathrm{SiO}_{2}$ (over $50 \%$ ) and $\mathrm{Al}_{2} \mathrm{O}_{3}$ (over 20\%). 
Table 2. Chemical composition of the samples

\begin{tabular}{|c|c|c|c|}
\hline \multirow{2}{*}{ Components } & \multicolumn{3}{|c|}{ Content [\%] } \\
\cline { 2 - 4 } & FA 1 & FA 2 & PC \\
\hline $\mathbf{S i O}_{\mathbf{2}}$ & 54.32 & 50.38 & 20.92 \\
\hline $\mathbf{A l}_{2} \mathbf{O}_{\mathbf{3}}$ & 22.73 & 26.43 & 5.81 \\
\hline $\mathbf{F e}_{2} \mathbf{O}_{\mathbf{3}}$ & 7.51 & 8.77 & 3.55 \\
\hline $\mathbf{C a O}$ & 6.40 & 7.18 & 63.07 \\
\hline $\mathbf{M g O}$ & 2.72 & 1.94 & 1.86 \\
\hline $\mathbf{S O}_{3}$ & 1.80 & 2.14 & 1.89 \\
\hline $\mathbf{T i O}_{2}$ & 0.66 & 0.42 & $/$ \\
\hline $\mathbf{N a}_{\mathbf{2}} \mathbf{O}$ & 0.58 & 0.21 & 0.20 \\
\hline $\mathbf{K}_{\mathbf{2}} \mathbf{O}$ & 0.97 & 0.63 & 0.74 \\
\hline $\mathbf{M n O}$ & $/$ & $/$ & 0.09 \\
\hline $\mathbf{C l}$ & $/$ & $/$ & 0.003 \\
\hline $\mathbf{C a O}_{\mathbf{n}}$ free & 0.23 & 0.59 & $/$ \\
\hline $\mathrm{SiO}_{\mathbf{2}}$ active & 30.45 & 27.87 & $/$ \\
\hline $\mathbf{L O I}$ & 2.08 & 2.36 & 0.96 \\
\hline
\end{tabular}

\subsection{Processing of fly ash samples}

Particle size analysis of the original fly ash samples is shown in Fig. 1. This figure shows that mass content of particles larger than 45 microns is $65.4 \%$ and $62.5 \%$ for FA 1 and FA 2 , respectively.

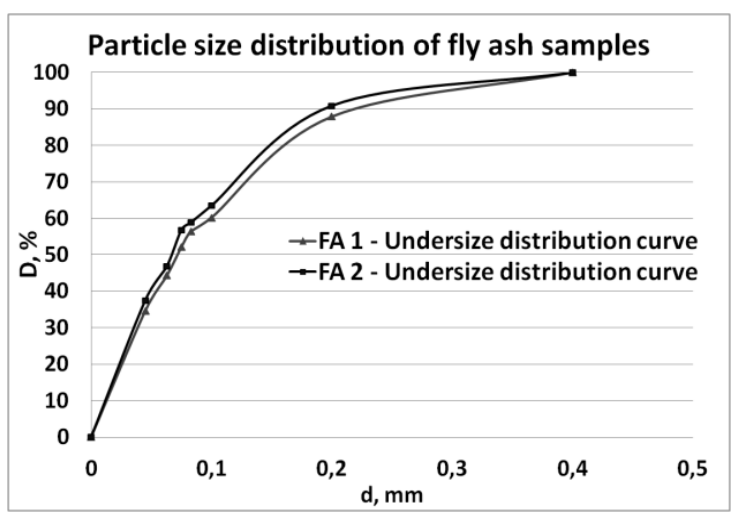

Figure 1. Particle size analisys of initial samples of fly ash
Considering the standard norms [ASTM C618], it is evident that original fly ash samples do not meet the necessary fineness (mass ratio of class +45 microns should not be more then 34\%).

In order to improve characteristics of fly ash samples in terms of their fineness and meet standard requirements, the samples were treated by different physical methods mechanical activation, grinding and classification.

Mechanical activation was performed in the vibrating ring mill for 30 minutes. Grinding was carried out in a laboratory ball mill during the 18 and 16.5 minutes for FA 1 and FA 2, respectively. According to particle size analysis of the initial samples (Fig. 1) satisfactory fineness [ASTM C618] of both fly ashes can be achieved using dry sieving method. Opening size of appropriated screen was $0.075 \mathrm{~mm}$. Particle size distributions of treated samples are shown in the Figures 2 and 3 .

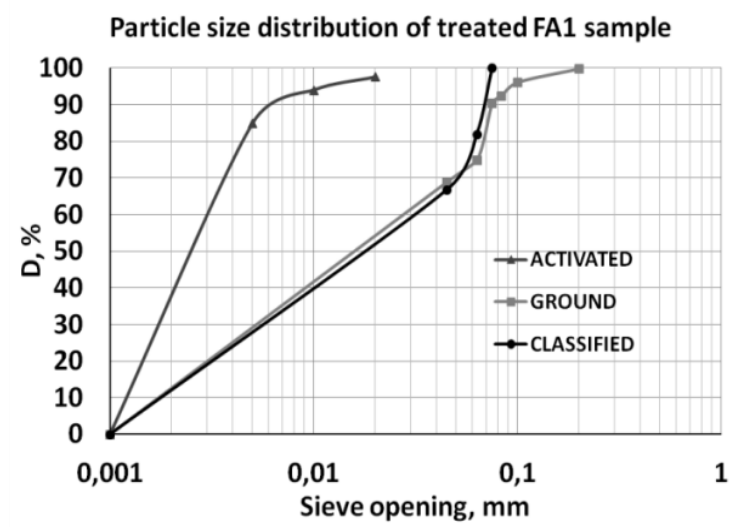

Figure 2. Particle size analisys of FA 1 sample, treated by different physical methods

Specific surface area was determined by Blaine method according to standard procedure. The time, indispensable for standard liquid passing between two levels 
marked on $U$ pipe of Blaine permeabilimeter was measured.

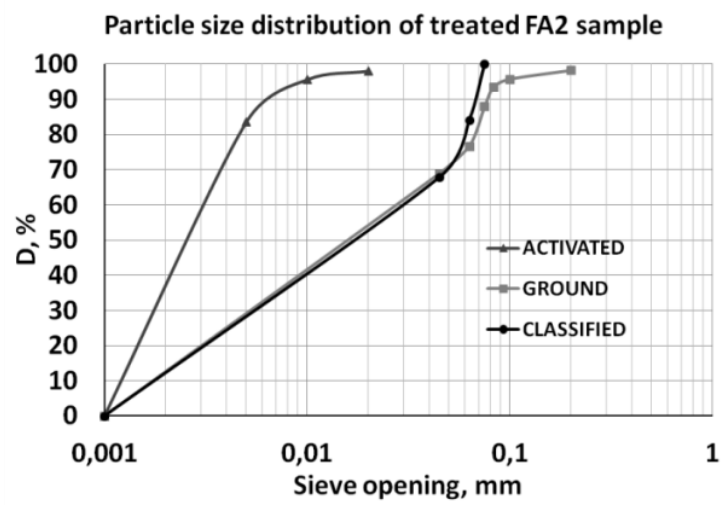

Figure 3. Particle size analisys of FA 2 sample,treated by different physical methods

Based on that time, density of fly ash, volume of metal cell for fly ash placing and adopted porosity of sample, specific surface area was calculated. The results are presented by Table 4.

Table 3. Standard requirements for pozzolanic activity [SRPS B.C1.018]

\begin{tabular}{|c|c|c|}
\hline \multirow{2}{*}{$\begin{array}{c}\text { Class of } \\
\text { Pozzolan }\end{array}$} & \multicolumn{2}{|c|}{ Minimal strengths [MPa] } \\
\cline { 2 - 3 } P 5 & flexural & compressive \\
\hline P 10 & 2.0 & 5.0 \\
\hline P 15 & 3.0 & 10.0 \\
\hline
\end{tabular}

\subsection{Pozzolanic activity testing}

Pozzolanic activity index with Portland cement is determined by standard procedure [ASTM C311; ASTM C618]. In this test method the 7 days and 28 days compressive strengths of a mortar prepared with a $20 \%$ fly ash substitution for cement on a mass basis are compared to those of a control mortar. While the control mortar is prepared with a water-to-cement ratio by mass (w/c) of 0.5 , the water content of the test mixtures is adjusted to provide an equivalent flow to that measured for the control. The mixture with the fly ash should provide $75 \%$ of the strength of the control at 7 days or 28 days, according to the ASTM C618 specification.

Pozzolanic activity index $\left(\mathrm{I}_{\mathrm{r}}\right)$ was counted by formula (1):

$I_{r}=\frac{A}{B} \cdot 100 \%$

where:

A - compressive strength of mortar with fly ash, after 7 or 28 days settings

B - compressive strength of referential (control) mortar, after 7 or 28 days settings

Pozzolanic activity with lime was determined by mechanical method according to Serbian Standard [SRPS B.C1.018]. Examination was carried out on the prisms of mortar (dimensions $4 \times 4 \times 16 \mathrm{~cm}$ ) created from hydrated lime, fly ash, standard sand and water, in mass ratio 1:2:9:1.8.

Moulds with fresh prepared mortar were put into a hermetic tin box at $20^{\circ} \mathrm{C}$ temperature for 24 hours \pm 15 minutes, and subsequently they kept in a temperaturecontrolled chamber at $55^{\circ} \mathrm{C}$ temperature for 5 days and 20 hours. After that, prisms were cooled, then removed from moulds and put into a moisture atmosphere. From preparation of mortar mixture to the examination of prisms should run 7 days altogether. Prisms were tested for compressive and flexural strength in the appropriated device. According to their pozzolanic activity, corresponding standard [SRPS B.C1.018] divide pozzolans into 3 classes (Table 3 ). The results of pozzolanic activity tests are shown in the Table 4. 
Table 4. Specific surface area and pozzolanic activity of fly ash samples in dependence on the fly ash treatment

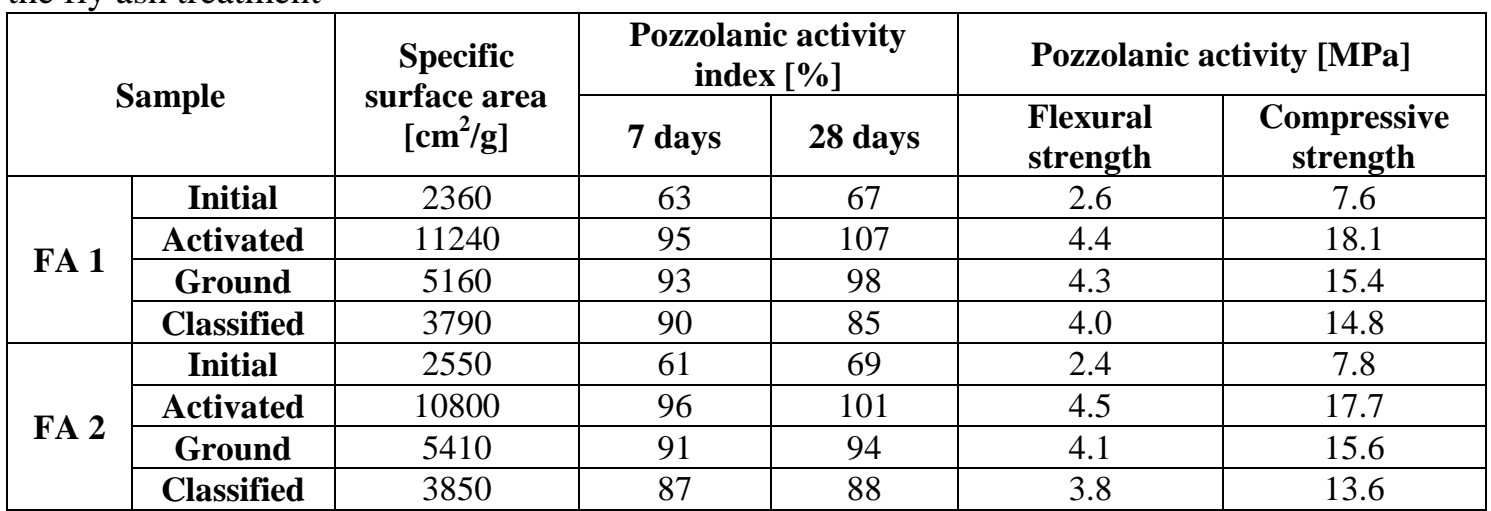

\section{Results and discussion}

Table 4 presents the results of the mentioned laboratory examinations.

As it can be concluded from Table 4, pozzolanic activity of both fly ashes can be significaly improved by different physical treatments of fly ash. The best results are obtained if the fly ash is treated by mechanical activation process. Mechanical activation can induce considerable increasement of pozzolanic activity index: 1,5 times after 7 days hardening and 1,6 times after 28 days hardening (for fly ash FA 1) and 1,57 times after 7 days hardening and 1, 46 times after 28 days hardening (for fly ash FA 2). Grinding and classification of fly ashes (to achieve the appropriate fineness) can also bring about enhancement of their pozzolanic activity.

It is obvious that, considerable part of combustible and coarse poorly reactive particles is removed by sieving process, which affects improvement in pozzolanic reactions. However, better results are obtained applying the grinding procedure. Apparently, process of comminution enables particle surface opening and thus, provides fast reaction between aluminosilicate particles of fly ash and hydrated calcium oxide from Portland cement. By mechanical activation (which presents very fine grinding) the best surface opening and the most complete reaction is accomplished.

Considering fly ash reaction with lime, it can be noticed that initial samples of both fly ashes can be classified into the lowest class of pozzolans (P5). After mechanical activation and grinding, fly ash samples can be classified into the highest class of pozzolans (P15). According to mentioned above, sieving treatment of fly ash also causes increasement of mortar strengths, therefore sieved fly ashes can be classified into P10 class of pozzolans.

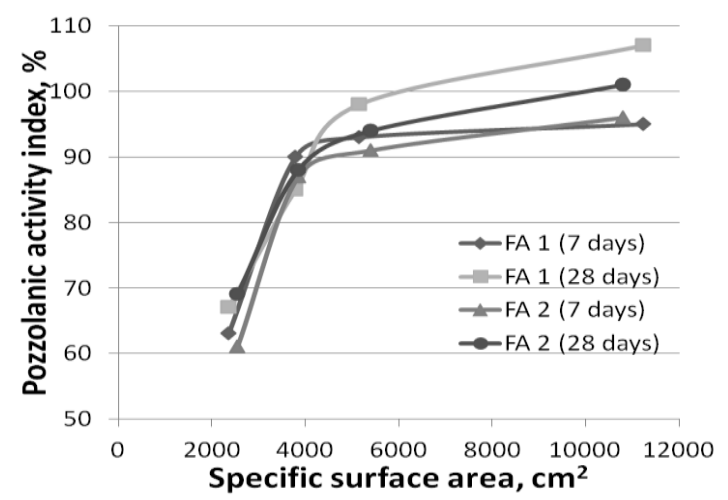

Figure 4. Pozzolanic activity index depending on the specific surface area of fly ash

Finally, it can be concluded that pozzolanic activity of fly ash depends on its specific surface area (as confirmed in literature). 
Pozzolanic activity index obviously increases with increased surface area (Fig 4). Therefore, fly ashes with the highest value of specific surface area have the best pozzolanic properties.

\section{Conclusion}

The results obtained in these examinations indicate that, after different physical treatments of fly ashes from two Serbian Thermal Power Plants, their pozzolanic activity can be considerable improved.

The best results are achieved by mechanical activation of fly ashes. This can be explained as follows. Mechanical activation process provides size reduction and also creation of new surfaces of fly ash particles. On that way calcium hydroxide becomes homogeneously distributed on the surfaces of the fly ash particles. Some investigations established that amorphous glass phase, which is carrier of pozzolanic properties, is more concentrated in internal layers of fly ash particles then in external. Besides that, additional amorphization of the fly ash particle surface takes place by mechanical activation process. These phenomena improve the pozzolanic activity towards a reaction with calcium hydroxide.

Considering other properties of fly ashes like chemical composition and fineness, and standard requirements, it can be concluded that both fly ashes can be used as a quality binder material; not only as a substitute for cement, but as a main binder for mortar and concrete products. Future investigation should be directed at the examination of their pozzolanic activity after 90 and more days hardening.

\section{Acknowledgement}

This paper was realized as a part of the projects: No. 34006: "Mechanochemical treatment of insufficiently quality mineral raw materials" and No. 37001: "Impact of mining waste from RTB Bor to pollution of watercourses and proposed measures and actions to reduce harmful impacts on the environment", which are funded by means of the Ministry of Education and Science of the Republic of Serbia.

\section{References}

[1] Agarwal, S.K. (2006) Pozzolanic activity of various siliceous materials. Cement and Concrete Research, 36, 1735-1739.

[2] Andrić, Lj., Aćimovć-Pavlović, Z., Petrov, M., Kostović, M., Jovanović, I., Bartulović, Z. (2012) The type of mechano-activator effect on mechanical activation of fly ash. Journal of Mining and Metallurgy, 48 A (1), 13-22.

[3] Biricik, H., Aköz, F., Berktay, İ., Tulgar, A. N. (1999) Study of pozzolanic properties of wheat straw ash. Cement and Concrete Research, 29, 637-643.

[4] Cheriaf, M., Cavalcante Rocha, J., Pera, J. (1999) Pozzolanic properties of pulverized coal combustion bottom ash. Cement and Concrete Research, 29, 1387-1391.

[5] Chindaprasirt, P., Homwuttiwong, S., Sirivivatnanon, V. (2004) Influence of fly ash fineness on strength, drying shrinkage and sulfate resistance of blended cement mortar. Cement and Concrete Research, 34, 1087-1092.

[6] Chindaprasirt, P., Buapa, N., Cao, H.T. (2005) Mixed cement containing fly ash for masonry and plastering work. Construction and Building Materials, 19, 612-618.

[7] Cordeiro, G.C., Toledo Filho, R.D., Fairbairn, E.M.R., Tavares, L.M.M., Oliveira, C.H. (2004) Influence of mechanical grinding on the pozzolanic activity of residual sugarcane bagasse ash. International RILEM Conference on 
the Use of Recycled Materials in Building and Structures, Barcelona, 731740.

[8] Fečko, P., Kušnierová, M., Raclavská, H., Čablík, V., Lyčková, B. (2005) Fly Ash, Ostrava.

[9] Jovanović, I., Bugarinović, S., Obradović, Lj. (2012) Mehaničke karakteristike maltera koji sadrži leteći pepeo tretiran različitim fizičkim postupcima. Rudarski radovi, 4/2012, 161 - 184. (in Serbian)

[10] Ranganath, R.V., Bhattacharjee, B., Krishnamoorthy, S. (1998) Influence of size fraction of ponded ash on its pozzolanic activity. Cement and Concrete Research, 28 (5), 749-761.

[11] Sánchez de Rojas, M.I., Frías, M. (1996) The pozzolanic activity of different materials, its influence on the hydration heat in mortars. Cement and Concrete Research, 26 (2), 203-213.

[12] Singh, M., Garg, M. (2007) Durability of cementing binders based on fly ash and other wastes. Construction and Building Materials, 21, 2012-2016.

[13] Standard ATSM C618

[14] Standard ASTM C311

[15] Standard SRPS B.C1.018

[16] Stefanović, G. (2007) Fenomeni i mehanizmi u sistemu portland cement - leteći pepeo u zavisnosti od karakteristika letećeg pepela, Doktorska disertacija, Univerzitet u Nišu, Mašinski fakultet, (in Serbian)

[17] Tangpagasit, J., Cheerarot R., Jaturapitakkul C., Kiattikomol K. (2005) Packing effect and pozzolanic reaction of fly ash in mortar. Cement and Concrete Research, 35, 1145-1151.

[18] Torii, K., Taniguchi K., Kawamura M. (1995) Sulfate resistance of high fly ash content concrete. Cement and Concrete Research, 25, 759-768.

[19] Trifunović, P., Zeković, M., Đukanović, N. (1999) Rudarski materijali, RGF, Beograd. (in Serbian) 